\title{
Utilization of Fermented Corn Cobs Flour in a Pellet-Shaped Ration AgainstMale Local Rabbit Carcasses (Oryctolagus cunniculus) Off Wean
}

\author{
Agung Baskoro, A H Daulay, E Mirwandhono, Yunilas, Y L Henuk \\ Animal Production Program Study, Faculty of Agriculture, University of North \\ Sumatera, \\ Medan 20155, Indonesia \\ E-mail: agungbaskoro2402@gmail.com
}

\begin{abstract}
Rabbits are livestock that can be used as a source of animal protein and have the potential to have meet national meat needs. Further development is needed whit good quality feed and affordable prices. The study aimed to evaluate feed containing corn cobs which were fermented by MOIYL against carcasses in local rabbits. The study was conducted in Bandar Klippa Deli Serdang Village, North Sumatra Province, in January March 2018. This study used 20 local rabbits with initial weights of $404.4 \pm 9.14$ grams and experimental designs using a completely randomized design (CDR), which consisted from 4 treatments and five replications. The treatment consisted of $\mathrm{P} 0=$ unfermented ration, $\mathrm{P} 1=$ $10 \%, \mathrm{P} 2=20 \%$, and $\mathrm{P} 3=30 \%$. The variables measured were cut weight, carcass weight, and carcass percentage. The results showed that corn cobs fermentation with probiotics MOIYL had a significant effect $(\mathrm{P}<0.01)$ and not significant $(\mathrm{P}>0.05)$, increasing corn cobs fermented by MOIYL to a level of $30 \%$ increasing slaughter weight and carcass weight, but does not increase the percentage of carcass.
\end{abstract}

\section{Introduction}

Rabbits are livestock that are expected to be able to help meet national meat needs. The potential for developing rabbits as meat-producing livestock is still very good, especially in North Sumatra. Besides the uncomplicated treatment, the rabbit size litter is also quite high which reaches 4-10 tails per birth. Within a year the kelici can give birth as much as 4-5 times Lebas et al., [8].

Rabbits also have meat with good nutritional content which has the potential as a provider of animal protein and has a fairly good percentage of carcass as much as $43-52 \%$ and adult females 50-59\% of the life weight of Farrel and Raharjo [5]. To produce a good carcass, rabbit feed needs must be considered. Good rabbit feed quality can increase rabbit productivity. The provision of forage feed in rabbits is not enough to meet the nutritional needs of rabbits so that additional concentrate feed is needed to help meet the nutritional needs of rabbits. Concentrate as a feed ingredient, will increase the cost of feed, so it is necessary to find cheap alternative feed ingredients while still considering the nutritional content and availability.

Corn is one of the cereal commodities that has a strategic role and has the opportunity to be developed because of its role as the main source of carbohydrates and proteins after rice. Almost all parts of corn plants can be used for various purposes, one of which is animal feed ingredients Bunyamin et al., [2]. Indonesia is a country with very high corn production. In North Sumatra alone, corn production in 2015 amounted to 1,519,407 tons of BPS North Sumatra [1]. 
One part of corn plant that can be used as animal feed material is corn cobs. Corn cob / janggelis waste obtained when corn seeds are shed from the fruit. Will be obtained shelled corn as its main product and the remaining fruit called cob or janggelRohani et al., [12].

Corn cobs have high crude fiber content, which is $46.52 \%$ and low protein, which is $2.67 \%$ Novriyanti [9], so processing is needed before being used as animal feed ingredients. Fermentation is one way to process corn cobs into feed ingredients which can be further enhanced by reducing the content of crude fiber and increasing protein content. So that corn cobs can be used as monogastric animal feed especially rabbits as concentrate feed with good quality and are expected to increase rabbit production

Indigenius Local Microorganisms are microorganisms that are exploited from their own substrate which have optimal ability to degrade Yunilas fiber [17]. According to Dwi [4], corn cobs inoculated with 5\% fungi Trichoderma sp. can reduce organic matter and increase crude protein content. Yulistiani et al. [15] reported that corn cobs fermented using Aspergillusniger microbes produced a crude protein content of $4 \%$ while corn cobs fermented with Trichodermavirede produced $3.4 \%$ protein. The composition of corn cob protein that has been fermented using microbes in general has increased, from 3\% to $6.1 \%$ inheritance [13]. Research Objectives To examine and determine the effect of using fermented corncob feed using MOIYL on digestibility of dry matter and organic matter for male local rabbits.

\section{Materials and Methods}

\subsection{Time and Place}

This research was conducted in Bandar Klifah Village, Deli Serdang Regency, North Sumatra Province. Laboratory of Animal Nutrition and Feed Sciences Animal Production Program Study, Faculty of Agriculture, University of North Sumatra and Laboratory of Goat Cut Research Station, SeiPutihGalang. This research lasts for 8 weeks starting from January 2018 - March 2018.

\subsection{Materials and Tools}

The materials used were 20 male local rabbits with an average initial body weight of 404.4 grams \pm 9.14. Pellet treatment consists of fine bran, corn, soybean meal, coconut cake, fermented corn cob, molasses, mineral mix, MOIYL Probiotic consisting of Bacillus sp YLB1, Trichodermasp YLF8 and Saccharomyces sp YLY3, drinking water, medicines and vitamins such as wormectin , B-complex, antibloat, rodalon as cage disinfectants.

The tool used is 20 cage units with a size of $50 \times 50 \times 50 \mathrm{~cm}$, a pellet printer, a body weight scale with a capacity of $15 \mathrm{~kg}$ with a sensitivity of $10 \mathrm{~g}$, an electric scale with a capacity of $3 \mathrm{~kg}$ with a sensitivity of $1 \mathrm{~g}$, a place to feed and drink in each cage with a total of 20 units, cage cleaning tools, cage lighting tools, chopper machines for chopping corn cobs, grinders to smooth feed ingredients and stationery to write data.

\subsection{Research Methods}

The research method used was experimental using a completely randomized design (CRD) consisting of 4 treatments and 5 replications. The treatments given are as follows:

P0: Ration without fermented corn cobs

P1: $10 \%$ fermented corn cobs

P2: $20 \%$ fermented corn cobs

P3: 30\% fermented corn cobs

Composition of research treatment (randomization of treatments and replications)

\begin{tabular}{lllll}
\hline $\mathrm{P}_{2} \mathrm{U}_{3}$ & $\mathrm{P}_{0} \mathrm{U}_{2}$ & $\mathrm{P}_{1} \mathrm{U}_{4}$ & $\mathrm{P}_{3} \mathrm{U}_{2}$ & $\mathrm{P}_{2} \mathrm{U}_{2}$ \\
$\mathrm{P}_{3} \mathrm{U}_{4}$ & $\mathrm{P}_{1} \mathrm{U}_{3}$ & $\mathrm{P}_{0} \mathrm{U}_{3}$ & $\mathrm{P}_{2} \mathrm{U}_{1}$ & $\mathrm{P}_{1} \mathrm{U}_{1}$ \\
$\mathrm{P}_{0} \mathrm{U}_{1}$ & $\mathrm{P}_{2} \mathrm{U}_{4}$ & $\mathrm{P}_{2} \mathrm{U}_{5}$ & $\mathrm{P}_{1} \mathrm{U}_{5}$ & $\mathrm{P}_{3} \mathrm{U}_{3}$ \\
$\mathrm{P}_{1} \mathrm{U}_{2}$ & $\mathrm{P}_{3} \mathrm{U}_{5}$ & $\mathrm{P}_{3} \mathrm{U}_{1}$ & $\mathrm{P}_{0} \mathrm{U}_{4}$ & $\mathrm{P}_{0} \mathrm{U}_{5}$ \\
\hline
\end{tabular}


2.4. Variables observed

Cut Weight (g/head)

Cutting weight is obtained by weighing the final weight of rabbits after fasting for 6-10 hours before slaughtering.

Carcass Weight (g/head)

Carcass weight is obtained from meat with rabbit bones that have been separated from the head to the base of the neck and from the left to the ankle boundary, contents of the abdominal cavity, blood, tail, and skin.

Carcass Percentage (\%)

Carcass Percentage is carcass weight compared to the weight cut multiplied by $100 \%$

$$
\text { Carcass Percentage }=\frac{\text { Carcass Weight }}{\text { Cut Weight }} \times 100 \%
$$

\subsection{Data analysis}

The data obtained were analyzed using analysis of variance (ANOVA) if between treatments there was a real effect then it would be continued by using Duncan's Distance Distinction Test.

\subsection{Implementation of Research}

Preparation of cages and equipment, preparation of rabbits, randomization of rabbits, processing of corn cobs, feeding and drinking, administration of medicines and data collection

\section{Results and Discussion}

\subsection{Cut Weight (g/head)}

Cutting weight is obtained from the results of weighing the final weight of rabbits after fasting for 7 hours. The data on male local rabbit cut weight results of the study can be seen in Table 1 below:

Table 1. Average cut weight of local rabbit ( $\mathrm{g} / \mathrm{head})$.

\begin{tabular}{lcccccc}
\hline Treatments & \multicolumn{3}{c}{ Replications } & & Average \pm Sd \\
& U1 & U2 & U3 & U4 & U5 & \\
\hline P0 & 1081 & 1093 & 954 & 1149 & 1054 & $1066,2 \pm 71,64^{\mathrm{C}}$ \\
P1 & 1092 & 998 & 1104 & 1195 & 1138 & $1105,4 \pm 72,12^{\mathrm{BC}}$ \\
P2 & 1192 & 1163 & 1205 & 1238 & 1166 & $1192,8 \pm 30,81^{\mathrm{AB}}$ \\
P3 & 1094 & 1208 & 1326 & 1396 & 1197 & $1244,2 \pm 118,14^{\mathrm{A}}$ \\
\hline
\end{tabular}

Remarks: Superscripts with different lowercase letters towards the columns, showed a very significant effect $(\mathrm{P}<0.01)$.

The results in the table were followed by analysis of variance, and the results were very significantly different $(\mathrm{P}<0.01)$ which can be seen in the appendix. After that Duncan's further test was carried out, the P3 results were not significantly different from P2, but significantly different from P1 and P0. P2 is not significantly different from P1, but it is significantly different from P0. This result is influenced by the consumption of different rations in each treatment. This statement is reinforced by Haryanto's statement [6] which states that the higher the amount of rations consumed allows the better growth (body weight gain) and ultimately will affect the weight of the rabbit cut.

Fermented feed with MOIYL can also increase protein content by $4 \%$ and reduce crude fiber content by $8 \%$. In addition, the digestibility level of fermented feed will also be higher. Hatmiko., Et al. [7] stated that the fermentation process can increase energy and protein content, reduce crude fiber content, and increase digestibility of low-quality food ingredients. So that the feed that has been fermented with MOIYL has an effect on the weight of the rabbit cut. 


\subsection{Carcass Weight}

Table 2. Average carcass weight of local rabbit carcass (g/head)

\begin{tabular}{lcccccc}
\hline Treatments & \multicolumn{3}{c}{ Replications } & & Average \pm Sd \\
\hline & U1 & U2 & U3 & U4 & U5 & \\
\hline P0 & 508 & 495 & 447 & 522 & 489 & $492,2 \pm 28,27^{\mathrm{C}}$ \\
P1 & 492 & 458 & 508 & 549 & 532 & $507,8 \pm 39,02^{\mathrm{BC}}$ \\
P2 & 554 & 517 & 566 & 576 & 524 & $546,4 \pm 25,88^{\mathrm{AB}}$ \\
P3 & 510 & 581 & 626 & 644 & 550 & $582,2 \pm 54,74^{\mathrm{A}}$ \\
\hline
\end{tabular}

Remarks: Superscripts with different lowercase letters towards the columns, showed a very significant effect $(\mathrm{P}<0.01)$.

From Table 2 above, the highest average carcass weight datum is found at $\mathrm{P} 3$, which is $582.2 \mathrm{~g}$. Then followed by P2 with an average of $546.4 \mathrm{~g}, \mathrm{P} 1$ with $507.8 \mathrm{~g}$, and the lowest at P0 with an average of 492.2g. These results are influenced by the weight and cut weight of rabbits. The higher the cut weight, the higher the carcass weight produced, in other words, the cut weight and carcass weight are positively correlated. This is consistent with the study of Prawirodigdo et al. [11] who reported that local rabbits with greater slaughter weight would produce even greater carcass weight. This is confirmed by the statement of Wibowo et al. [14] which states that carcass weight is strongly influenced by live weight before being cut, the higher the weight of the life before cutting, the higher the carcass weight produced.

Furthermore, analysis of variance was carried out and the different results were very real which can be seen in the appendix. This can be seen from the results of Duncan's further test which states that P3 is significantly different from $\mathrm{P} 1$ and $\mathrm{P} 0$, but not significantly different from $\mathrm{P} 2$. The results of further tests are influenced by the increasing addition of corn cobs flour that have been fermented with MOIYL which will reduce the crude fiber content. As Yunilas stated [16], MOIYL based on palm oil waste plays a role in degrading fiber (cellulose and hemicellulose) and can be used as a source of high fibrous feed fermentation inoculum. Low crude fiber will increase digestible proteins that can form and repair tendon tissue. This is reinforced by the statement of Nurhayati and Marsadayanti [9] who said that the crude fiber in the ration exceeds the needs of livestock so that livestock will need more energy to digest it so that the energy that can be used to digest protein and other food substances is reduced. This results in digestible proteins that can be utilized by livestock to form and repair the tendon tissue to be reduced.

\subsection{Carcass Percentage}

Carcass Percentageis fresh carcass weight divided by empty body weight multiplied by one hundred percent.

Table 3. Average percentage of male local rabbit carcass (\%)

$\begin{array}{lll}\text { Treatments } & \text { Replications } & \text { Average } \pm \mathrm{Sd}\end{array}$

\begin{tabular}{lcccccc}
\hline & U1 & U2 & U3 & U4 & U5 & \\
\hline P0 & 46,99 & 45,28 & 46,85 & 45,43 & 46,39 & $46,2 \pm 0,79^{\mathrm{a}}$ \\
P1 & 45,05 & 45,89 & 46,01 & 45,94 & 46,74 & $45,9 \pm 0,86^{\mathrm{a}}$ \\
P2 & 46,47 & 44,45 & 46,97 & 46,52 & 44,93 & $45,8 \pm 1,10^{\mathrm{a}}$ \\
P3 & 46,61 & 48,09 & 47,21 & 46,13 & 45,94 & $46,8 \pm 0,87^{\mathrm{a}}$ \\
\hline
\end{tabular}

The data in Table 3 above shows the highest average at P3 with an average of $46.8 \%$, followed by P0 with an average of $46.2 \%$, then P1 (45.9\%) and P2 (45.8\%) respectively. These results are in accordance with the statements of Farrel and Raharjo [5] which state that the factors that influence the 
percentage of carcass are slaughter age and sex. 5-month-old male rabbits produce $46 \%$ carcass and $44 \%$ female. 8-month-old male rabbits produce carcasses of 50\% and females 55\%. An adult male rabbit can produce carcasses as much as $43-52 \%$ and adult females $50-59 \%$ of their life weight.

After analysis of variance, the results were not significantly different. Further tests that have been carried out also show that P3 is not significantly different from P2, P1, and P0. This result is influenced by the increased weight weight which will be followed by an increase in carcass weight so that the carcass percentage value is relatively no different. The percentage of carcass is influenced by carcass weight and live weight. Carcass percentage is an important value for determining broiler livestock production. The above statement is reinforced by the statement of Dewi et al. [3], which states that the percentage value of carcasses can show almost the same results. This is because the increase in cutting weight is followed by an increase in carcass weight, so the percentage of carcass produced is relatively the same.

\section{Conclusion}

Utilization of fermented corn cobs using MOIYL up to level 30\% can increase slaughter weight and carcass weight, but shows insignificant results on carcass percentage.

\section{References:}

[1] Central Statistics Agency of North Sumatra Province. 2015. Extensive Harvesting and Corn Production. Http://sumut.bps.go.id/frontend/linkTabelStatis/view/id/202. [February 20 $\left.{ }^{\text {th }}, 2017\right]$

[2] Bunyamin, Z., Efendi, R., and Andayani, N.N. 2013. Utilization of Corn Waste for Animal Feed Industry.National Seminar on Agricultural Technology Innovation.Research Center for Cereal Crops in Maros.

[3] Dewi, S.C.H., E.Purnawan and M.Djalil. 2012. Local Rabbit Carcass and Non Carcass Production at Different Ages and Genders. Proceedings of FAI Semnas.University of MercuBuana.Yogyakarta.

[4] Dwi, Y, A. 2015. Content of Organic Ingredients and Rough Proteins of Corn Cob (Zea Mays) Inoculated with Fungi Trichoderma Sp. at Different Incubation Durations. Essay.Hassanudin University Faculty of Agriculture.Macassar.

[5] Farrel, D.J. dan Y.C. Rahardjo. 1984. The Potensial for Meat Production from Rabbit. PusatPenelitiandanPengembanganPeternakan. Bogor.

[6] Haryanto, B. 2006. Improvement of Rabbit Carcass Growth and Production Through Giving Temulawak (Curcuma XanthorrhizaRoxb) on Rations. General Soedirman University Faculty of Animal Husbandry.Purwokerto.

[7] Hatmiko, S.P., Cholis, N. and Soejosopoetro, B. 2013. Effect of Fermented Feed Using Azotobacther Bacteria Against pH, Water Binding, and Cooking Shrinkage of Rabbit Meat.Brawijaya University. Poor

[8] Lebas, F., P.Coudert.,R.Rouvier\& H. De Rachambeau. 1986. The Rabbits, Husbandry, Health and Production. Food Agriculture Organization of the United Nation, Rome.

[9] Novriyanti, S. 2015. Effect of Giving Corn Cob Wafers Containing Various Types of Feed Material Protein Source to Metabolism of Nitrogen Goat.Essay.Hasanuddin University Faculty of Animal Husbandry.Makassar.

[10] Nurhayati, N. Marsadayanti. 2005. Effect of the Use of Noni Fruit Flour in Rations on the Weight of Carcasses of Broiler Chicken. Journal of Tropical Livestock Development.Jambi University Faculty of Animal Husbandry.Jambi.

[11] Prawirodigdo, S., V.U.Subiyanti., G.Purwanto and B.Sudarmoyo. 2005. Inclusion of Fresh Ipomoea Aquatic in the Diets of Growing Indonesian Native Rabbits: A Preliminary Study. Journal of Development of Tropical Livestock 30: 1-6.

[12] Rohaeni, E.S., A. Subhan and A. Darmawan. 2006. Complete Feed Usage Study by Utilizing Corn Janggel Against Cow Growth. Pros. National Workshop on the Development of the Corn-Cow Integration System. Pontianak, 9-10 August 2006. Animal Husbandry Research Center.Bogor Agricultural Institute. 
[13] Warisman. 2014. Biological Processing in Improving Nutritional Quality of Fermented Corn Cobs as Sheep Feeds. Thesis. Animal Husbandry Study Program, Faculty of Agriculture, University of North Sumatra, Medan

[14] Wibowo, R.Y. J. Riyanto and YBP Subagyo. 2013. Effect of Use of Tea Dregs (Camellia Sinensis) in Rations on New Zealand White Male Rabbit Carcass Production. Biopharmaceutical vol. no.1, pp. 11-17.

[15] Yulistiani, D. 2012. Corn Cob Silage for Ruminant Feeds.Tabloid Sinartani Agricultural Research Agency. Issue 18-24 July 2012 No. 3466

[16] Yunilas. 2016. The Role of Indigenous YL (MOIYL) Microorganisms as Fiber Degradation Inoculums Based on Palm Oil Waste. Proceedings of the National Seminar on Sustainable Livestock 8, 16 November 2016.Sumedang. Indonesia.

[17] Yunilas, LiliWarly, YettiMarlida., AndIrsanRyanto. 2013. Protency of IndeginousBakteriaFrom Oil Palm Waste in Degrades Lignocellulose as a Sources of Inoculum Fermented to High Fiber feed. Pakistan Journal of Nutrition 12 (9): 851-853. 